\title{
KAJIAN POTENSI PERENCANAAN WILAYAH KOTA BINJAI SUMATERA UTARA
}

\author{
Dr. Yuanita F.D Sidabutar, ST., M.Si \\ Dr. Edi Indera, ST.,M.Si \\ Program Studi Magister Perencanaan Wilayah \\ Universitas Batam \\ Email: yuanita.fd@univbatam.ac.id \\ edi.indera@univbatam.ac.id
}

The potential of Binjai City is the border area of Medan City and areas outside Medan City (Aceh, Langkat, Stabad and others). The city of Binjai has 5 sub-districts with 37 villages. Located approximately $25 \mathrm{~km}$ from the center of Medan City, Binjai City is a city that has the potential to become a transit city with its boundaries that can reach many areas so that transportation facilities must be developed as much as possible. Objectives 1) Understand information on the potential of the Binjai City area. 2) Knowing the condition of the potential development of Binjai City. 3) Informing the development of the potential of the Binjai City area. Binjai City. The study data on the potential for regional planning of Binjai City has 1) Binjai City has culinary potential 2) Binjai City has transit terminal facilities, 3) Binjai City has tourism places in several villages. The results of this study were carried out using analytical techniques from survey results to the field in the form of analysis of the condition of regional potential, and data from the distribution of questionnaires in the form of percentage statistical analysis results. And also obtained the concept of thinking for how to increase the economic value of Binjai City.

\section{Keywords: Binjai City, Regional Planning, Regional Potential}

Potensi Kota Binjai merupakan wilayah perbatasan Kota Medan dan wilayah diluar Kota Medan \{Aceh, Langkat, stabad dan lainnya). Kota Binjai ini memiliki 5 kecamatan dengan 37 kelurahan. Berjarak kurang lebih 25 km dari pusat Kota Medan, Kota Binjai merupakan kota yang berpotensi menjadi kota transit dengan batas wilayahnya yang dapat mencapai banyak wilayah sehingga fasilitas transportasinya harus dikembangkan semaksimal mungkin. Tujuan 1) Memahami informasi potensi wilayah Kota Binjai. 2) Mengetahui kondisi pengembangan potensi Kota Binjai.3) Menginformasikan perkembangan potensi wilayah Kota Binjai. Kota Binjai. Data kajian potensi perencanaan wilayah Kota Binjai ini memiliki 1) Kota binjai memiliki potensi kuliner 2) Kota Binjai memiliki fasilitas terminal transit, 3) Kota Binjai memiliki Tempat pariwisata dibeberapa kelurahannya. Hasil dari penelitian ini dilakukan dengan teknik analisis dari hasil survey ke lapangan berupa analisis kondisi potensi wilayah, dan data dari hasil pembagian kuesioner berupa hasil analisis statistik presentase. Dan juga diperoleh konsep pemikiran untuk bagaimana cara meningkatkan nilai perekonomian Kota Binjai.

Kata kunci : Kota Binjai, Perencanaan Wilayah, Potensi wilayah 


\section{PENDAHULUAN}

Kota Binjai adalah salah satu kota dahulu daerah tingkat II berstatus kota madya. Dalam wilayah provinsi Sumatera Utara, Indonesia. Binjai terletak $22 \mathrm{~km}$ di sebelah barat ibu kota provinsi Sumatera Utara, Medan. Sebelum berstatus kotamadya, binjai adalah ibu kota kabupaten langkat yang kemudian dipindahkan ke stabat. Binjai berbatasan langsung dengan kabupaten langkat ini di sebelah barat dan utara serta kabupaten deli serdang di sebelah timur dan selatan. Binjai merupakan salah satu daerah dalam proyek pembangunan MEBIDANGRO yang meliputi kawasan medan, binjai, deli sedang dan karo. Saat ini, Binjai dan Medan dihubungkan oleh jalan raya lintas sumatera yang menghubungkan antara Medan dan Banda Aceh. Oleh karena ini binjai terletak di daerah strategis di mana merupakan pintu gerbang kota Medan ditinjau dari provinsi Aceh. Posisi kota Binjai cukup strategis untuk menjadikannya berkembang pesat sebagai kota perdagangan karena terletak di jalur lintas Sumatera. Jalur ini menghubungkan kota Binjai dengan kota atau di kabupaten di Sumatera Utara, seperti kota Medan, Kabupaten Langkat, dan provinsi daerah istimewa Aceh.

Selain dikenal sebagai kota dagang, Binjai juga dikenal sebagai kota penghasilan rambutan. Luas areal perkembangan rambutan di Kota Binjai saat ini mencapai 425Ha dengan jumlah produksi sekitar 2400 ton pertahun. Selain sebagai buah segar, buah rambutan juga di olah menjadi selai atau buah kaleng.

Beberapa potensi wiliayah dari Kota Binjai ini adalah di sektor pertanian, terutama tanaman padi, dimana pada tahun
2002 jumlah produksinya mencapai 22.266 ton. Walaupun hasil pertanian ini cukup potensial (kegiatan perekonomian terbesar ketiga dari Kota Binjai), namum demikian sektor yang lebih menonjol dalam kegiatan perekonomian daerah adalah sektor industri pengolahan dan perdangangan. Sedangkan potensi peternakan sebagian besar penghasil ternak di kota Binjai adalah berada di kecamatan Binjai Selatan. Sebaran penduduk di kota Binjai sebagian besar terdapat di kecamatan Binjai Utara dengan luasan $23,59 \mathrm{~km} 2$ dan kepadatan penduduk sebesar $2.616 \mathrm{jiwa} / \mathrm{km} 2$. Angka ini masih tergolong kecil jika dibandingkan dengan kepadatan penduduk di kecamatan Binjai Kota yaitu 8005 jiwa/km2. Hal ini disebabkan karena luasan daerahnya pun kecil yaitu $4.12 \mathrm{~km} 2$ dengan jumlah penduduk sebesar 32.979 jiwa. Kecamatan dengan tingkat kepadatan tertinggi yaitu kecamatan binjai kota (8005 jiwa/km2), sedangkan kecamatan denagan tingkat kepadatan terendah yaitu kecamatan binjai selatan (1.360 jiwa/km2).

Pada tahun 2002 PDB Kota Binjai atas dasar harga berlaku bernilai 114.697.633 juta rupiahatau naik 15\% jika dibandingkan dengan tahun 2001 sebesar 100.123.582 juta rupiah. Dari data tahun 2000, konstribusi yang cukup signifian membangun perekonomian Kota Binjai yaitu sektor industri pengolahan (29.18\%), kemudian diikuti oleh sektor perdagangan, hotel dan restoran $(28,85 \%)$ dan sektor pertanian(11,21\%). Sedangkan sektor lainnya $(30,75 \%)$ meliputi sektor pertambangan, pengangkutan, dan komunikasi, jasa-jasa, pertanian, bangunan, listrik, gas, air bersih, dan keuangan. 


\section{POTENSI WILAYAH KECAMATAN KOTA BINJAI}

Kota Binjai adalah kota yang terdiri

dari 5 kecamatan dan masing-masing kecamatan terdiri dari beberapa kelurahan. antara lain :

\section{Kecamatan Binjai Kota}

Binjai Kota dengan luas daerah $4.12 \mathrm{~km} 2$ dan ketinggian berkisar 30MDPL dengan luas daerah tersebut Binjai kota juga memiliki 7 kelurahan, diantaranya adalah :

1) Kelurahan bemgam,

2) Kelurahan binjai,

3) Kelurahan kartini,

4) Kelurahan Pekan Binjai (pusat pemerintahan),

5) Kelurahan satria (pusat pendidikan),

6) Kelurahan Setia, Kelurahan Tangsi.

Wilayah Binjai kota memiliki potensi, diantaranya adalah untuk daerah komersial dan pusat perekonomian; potensi pariwisata untuk pariwisata terdapat taman balita yang berada di jalan veteran, taman PKK yang terdapat di jalan sudirman, taman remana yang berada di jalan sudirman, kuliner rumah makan nasi timbel, lapangan merdeka kota(ada sarana bermain kuda), dan pusat pasar tayib; untuk potensi masyarakat dominan bekerja sebagai pedagang (872 jiwa) dan pekeja PNS 821 orang.

\section{Kecamatan Binjai selatan}

Binjai Selatan dengan luasan 29.96km2 dengan ketinggian 30MDPL memiliki 8 kelurahan dan di antaranya adalah:

1) Kelurahan bakti karya(PM),

2) Kelurahan Binjai Estase,

3) Kelurahan Pujidadi,

4) Kelurahan rambu barat,

5) Kelurahan rambung dalam,

6) Kelurahan rambung timur,
7) Kelurahan Tanah merah,

8) Kelurahan Tanah Seribu.

Kecamatan Binjai Selatan terkenal di bidang perkebunan, salah satunya kelurahan tanah seribu merupakan penghasil rambutan terbesar di Kota Binjai. Dan untuk pariwisata terdapat pantai $\mathrm{SB}$, pemandian asam namo ungkur, bukit lawing, kesenian kuda kepang, kuliner jadi resto pasar rambung. Sedangkan untuk masyarakat sebagian besarnya bekerja sebagai petani dengan jumlah 1863 jiwa dan bekerja sebagai pedangang berjumlah 1670 jiwa

\section{Kecamatan Binjai Utara}

Dengan luasan tanah $23.59 \mathrm{~km} 2$ dan ketinggian 30MDPL, Binjai Utara memiliki sembilan kelurahan diantaranya:

1) Kelurahan cengkeh turi,

2) Kelurahan damai,

3) Kelurahan jati karya,

4) Kelurahan jati utomo,

5) Kelurahan jati Negara,

6) Kelurahan kebun jada(PM),

7) Kelurahan nangka,

8) Kelurahan pahlawan,

9) Kelurahan tamda, hulu.

Selain terkenal sebagai daerah perindustrian, binjai utara juga memiliki potensi pariwisata yang diantaranya taman PGRI di jalan. Amir Hamza, peternakan kelinci di jalan perintis kemerdekaan, vihara kuan tee bio pada jalan Belitung, kuliner masakan daging kelinci dan pada jalan perintis kemerdekaan merupakan pusat kebun dan pasar lada. Di daerah binjai utara masyarakat lebih dominan bekerja sebagai pedagang (3043 jiwa) dan petani (2830 jiwa) dan sebagai tukang bangunan sebanyak 2805 jiwa.

\section{Kecamatan Binjai Timur}

Binjai Timur memiliki luasan $2.170 \mathrm{~km} 2$ dan ketinggian 30 MDPL dengan luasan tersebut 
Jurnal Potensi

Program Studi Magister Perencanaan Wilayah Universitas Batam

Volume I, Issue 1, Maret 2021, Page 36-49

Binjai Timur terpecah menjadi 7 kelurahan diantaranya adalah:

1) Kelurahan dataran tinggi,

2) Kelurahan mencirim,

3) Kelurahan sumber karya,

4) Kelurahan sumber muliorejo,

5) Kelurahan tanah tinggi(PM),

6) Kelurahan timbang langkat,

7) Kelurahan tunggu room.

Kecamatan ini terkenal dalam bidang pertanian, untuk pariwisata terdapat masjid agung binjai, binjai supermall dan pasar renganu. mayoritas masayarakat bekerja sebagai pedagang (6.331 jiwa).

\section{Kecamatan Binjai Barat}

Binjai barat memiliki luasan $1.086 \mathrm{~km} 2$ dengan ketinggian 30MDPL dengan luasan tersebut Binjai barat memiliki 6 kelurahan di antaranya:

1) Kelurahan Bandar senembah (PM),

2) Kelurahan limau mungkur,

3) Kelurahan limau sundai,

4) Kelurahan paya robah,

5) Kelurahan suka maju,

6) Kelurahan suka ramai.

Sebagai daerah peternakan, binjai barat juga memiliki daerah untuk pariwisata yang terdapat taman titi kembar dan bukit lawing pasar brahrang, untuk potensi masyarakat dominan bekerja sebagai pedangang(2537 jiwa) dan berprofesi sebagai TNI 717 jiwa.

\section{Peran Strategis Daerah Transit dalam Industri Pariwisata}

Daerah transit adalah daerah di mana wisatawan akan melewati daerah tersebut dalam perjalanan menuju destinasi pariwisata. Tidak semua wisatawan akan berhenti di daerah transit, tapi mereka pasti akan melewatinya, bahkan kadang-kadang perjalanan mereka justru berakhir di daerah transit jika wisatawan tersebut menemukan sesuatu yang lebih menarik daripada destinasi pariwisata yang hendak dituju. Partisipasi daerah transit dalam industri pariwisata bergantung pada bagaimana daerah tersebut bisa memanfaatkan posisinya untuk menarik wisatawan dengan baik. Daerah transit sebenarnya adalah daerah yang cukup strategis untuk bisa berperan dalam industri pariwisata. Jika dikelola secara baik dan profesional dengan mempertimbangkan potensi dan sumber daya daerahnya, maka daerah transit bisa menjadi daerah tujuan akhir dari wisatawan. Industri pariwisata mengacu pada semua aktivitas yang menawarkan dan menjual produk-produk pariwisata. Menurut Middleton, (2009: 20) produk pariwisata didefinisikan sebagai "A bundle or package of tangible and intangible component, based on activity at destination. The package is perceived by the tourist as an experience available at price." Ini berarti bahwa produk pariwisata adalah semua bentuk aktivitas manusia yang terjadi di daerah destinasi. Dengan demikian sebenarnya produk pariwisata itu bukan hanya atraksi saja, tapi meliputi semua aktivitas wisatawan, seperti menikmati, melihat, merasakan, mendengar, mengamati, dan membeli semua bentuk barang dan jasa yang ditawarkan di daerah destinasi. Sementara itu, Cooper (1990) dalam bukunya Tourism Principle and Practice, menjelaskan bahwa area wisata itu tidak hanya terdiri atas destinasi wisata itu sendiri, tetapi juga daerah asal dan daerah transit atau daerah yang dilewati oleh wisatawan selama melakukan kegiatan pariwisata. Tiga area tersebut mengambil peran penting dari sebuah industri pariwisata. Di daerah-daerah tersebut 
kegiatan industri pariwisata bisa dilakukan. Daerah asal adalah daerah di mana wisatawan tersebut tinggal sehari-harinya. Di daerah asal, biasanya wisatawan akan mencari semua informasi tentang destinasi pariwisata, memesan akomodasi dan tiket perjalanan. Daerah transit adalah daerah dimana wisatawan akan melewati daerah tersebut dalam perjalanan menuju destinasi wisata. Tidak semua wisatawan akan berhenti di daerah transit tapi mereka pasti akan melewatinya. Pada situasi tertentu, daerah transit dapat menjadi destinasi pariwisata jika wisatawan menemukan sesuatu yang lebih menarik daripada destinasi wisatanya sendiri. Partisipasi daerah transit dalam industri pariwisata bergantung pada bagaimana daerah tersebut bisa memanfaatkan posisinya untuk menarik wisatawan dengan baik. Sementara destinasi pariwisata adalah daerah yang menjadi tujuan akhir dari wisatawan. Di daerah ini, wisatawan akan menikmati atraksi-atraksi pariwisata. Daerah asal dan transit adalah daerah yang biasanya menjual produkproduk pendukung pariwisata, sedangkan destinasi pariwisata adalah daerah yang menawarkan produk inti dari kegiatan wisata. Produk pariwisata juga dapat diartikan sebagai bauran dari aneka sumber daya, fasilitas, dan jasa sebagaimana diungkapkan oleh Manuel Baud Bouvy dan Fred Lawson dalam bukuTourism and Recreation Handbook of Planning and Design (1998) yang mengatakan "Tourism products are an amalgam of resources, facilities, and services." Tiga macam produk tersebut merupakan produk utama dalam industri pariwisata. Ketiganya dapat ditemukan dalam area dasar pariwisata atau the basic system of tourism area. Khusus untuk sumber daya yang mengandung arti atraksi pariwisata, hanya dapat ditemukan di area destinasi pariwisata.

Sebuah destinasi seharusnya bisa menjadi semacam area penggerak bagi daerah-daerah lain untuk ikut berkembang. Kegiatan ekonomi yang terjadi di destinasi bisa dirasakan pula oleh daerah lain yang tercakup dalam area industri pariwisata. Daerah transit sebenarnya adalah daerah yang cukup strategis untuk bisa berperan dalam industri pariwisata. Singapura adalah contoh terbaik. Dulu Singapura merupakan daerah transit bagi wisatawan dan pebisnis yang akan mengunjungi Indonesia dan Australia. Kemudian, negara tersebut dengan upayanya yang inovatif, seperti sistem pajak yang lebih murah, birokrasi yang mudah, keamanan yang tinggi, dan pusat perbelanjaan yang modern dengan harga terjangkau, akhirnya menjadikan Singapura sebagai daerah wisata belanja dan bisnis yang paling disukai. Saat ini, Singapura menjadi negara peringkat pertama di Asia Tenggara dengan jumlah kunjungan wisatawan terbanyak. Padahal negara tersebut hanya kawasan kecil dengan sumber daya wisata yang terbatas. Hal yang sama pernah terjadi pada Cianjur. Sebelum jalan tol Cipularang dioperasikan, setiap wisatawan yang akan ke Bandung selalu melewati kota ini. Cianjur bisa memposisikan dirinya sebagai daerah transit yang disukai wisatawan dengan produk unggulan manisan buah. Kita bisa menyaksikan bagaimana wisatawan yang akan pergi ke Bandung selalu mampir ke Cianjur untuk membeli manisan sebagai oleh-oleh. Namun, sejak dibukanya jalan tol Cipularang, banyak industri manisan gulung 
tikar karena kekurangan pembeli. Cianjur masih belum bisa menjadi daerah tujuan akhir wisatawan walaupun pernah menjadi daerah transit yang cukup berhasil.

Melihat potensi pariwisata di Indonesia dengan destinasi-destinasi unggulan, seperti Bali, Yogyakarta, Malang, Danau Toba, Gunung Bromo, Candi Borobudur, Pantai Pangandaran, Danau Kelimutu, Pulau Komodo, Wakatobi, dan lainnya, tentu di sanalah juga terdapat banyak daerah transit. Sebagian bisa berkembang dengan baik, namun lebih banyak lagi yang masih belum berbuat apa-apa. Untuk menjadi daerah transit yang disukai wisatawan memang membutuhkan perencanaan dan pengelolaan yang baik dengan melibatkan partisipasi dari pemerintah, swasta, dan masyarakat secara kolaboratif dan integratif. Perencanaan juga harus mempertimbangkan potensi dan sumberdaya dari daerah tersebut. Kebanyakan daerah transit memang bermain di area produk pariwisata yang berupa cinderamata atau produk makanan dan minuman, namun jika sebuah daerah transit juga mempunyai atraksi pariwisata alam yang unik, ini adalah keunggulan kompetitif yang layak untuk dikembangkan. Kadang tidak semua kebutuhan dan keinginan wisatawan bisa terpenuhi di destinasi, peluang inilah yang bisa dimanfaatkan oleh daerah transit untuk ikut bermain dalam industri pariwisata. Sebuah produk unggulan yang unik dan inovatif adalah solusi terbaik untuk mengembangkan daerah transit.

\section{METODE PENELITIAN}

Beberapa cara dilakukan untuk mengumpulkan informasi dan data yang berkaitan dengan penelitian. Metode-metode tersebut adalah sebagai berikut:

\section{Studi Literatur}

Studi yang mengumpulkan data dan informasi dari buku, jurnal ilmiah, artikel ilmiah, dan sebagainya sebagai referensi dan kutipan dari penulisan karya ilmiah ini.

\section{Studi Lapangan}

Pengumpulan data dari studi ini berasal dari lapangan langsung. Pengambilan data dan keterangan langsung dari lapangan dilakukan secara survei.

\section{Wawancara}

Pengumpulan data dan informasi dengan cara tanya jawab dengan narasumber yang ahli dalam bidangnya dan pembagian angket.

\section{HASIL DAN PEMBAHASAN}

Hasil data yang akan dipaparkan berdasarkan pembagian kuesioner data sosial dan kuesioner data teknis.

I. Jumlah kuisioner (data sosial) disebarkan kepada 25 responden mengenai Kota Binjai Sebagai Kota Transit dengan indikator antara lain yaitu umum, infrastruktur, harga, kenyamanan sehingga didapatkan data sebagai berikut:

Tabel 1. Data Responden Sosial

\begin{tabular}{|l|c|c|c|c|}
\hline \multirow{2}{*}{ KECAMATAN } & \multicolumn{3}{|c|}{ UMUR } & \multirow{2}{*}{ TOTAL } \\
\cline { 2 - 4 } & $\mathbf{1 1}-\mathbf{2 0}$ & $\mathbf{2 1}-\mathbf{3 0}$ & $\mathbf{3 1}-\mathbf{4 0}$ & \\
\hline Binjai Kota & & & & \\
\cline { 1 - 1 } Binjai Timur & 8 & 15 & 2 & 25 \\
\cline { 1 - 1 } Binjai Selatan & & & & \\
\hline
\end{tabular}

\begin{tabular}{|c|c|c|c|c|c|c|c|}
\hline \multirow{2}{*}{ KECAMATAN } & \multicolumn{6}{|c|}{ PEKERJAAN } & \multirow{2}{*}{$\begin{array}{c}\text { TOT } \\
\text { AL }\end{array}$} \\
\hline & D & $\mathbf{M}$ & $\mathbf{K}$ & $\mathbf{P}$ & PS & $\mathbf{W}$ & \\
\hline Binjai Kota & \multirow{3}{*}{3} & \multirow{3}{*}{10} & \multirow{3}{*}{8} & \multirow{3}{*}{2} & \multirow{3}{*}{3} & \multirow{3}{*}{2} & \multirow{3}{*}{25} \\
\hline Binjai Timur & & & & & & & \\
\hline Binjai Selatan & & & & & & & \\
\hline
\end{tabular}

Sumber: Sumber Data, 2020 
Jurnal Potensi

Program Studi Magister Perencanaan Wilayah Universitas Batam

Volume I, Issue 1, Maret 2021, Page 36-49

Keterangan:

- $\mathrm{D}=$ Designer

$\cdot \mathrm{M} \quad=$ Mahasiswa/i

- $\mathrm{K}$ = Karyawan

-P = Pelajar

- PS = Pekerja Swasta

- $\mathrm{W} \quad=$ Wirausaha

Berdasarkan hasil pendataan kuisioner di atas maka hasilnya berdasarkan 25 kuesioner diatas sebagai berikut:

\section{Umum}

a. Pernahkah anda pergi ke kota Binjai?

- $68 \%$ (17 orang) mengatakan pernah.

- $32 \%$ (8 orang) mengatakan tidak pernah.

Diagram 1. Data Pernah ke Kota Binjai

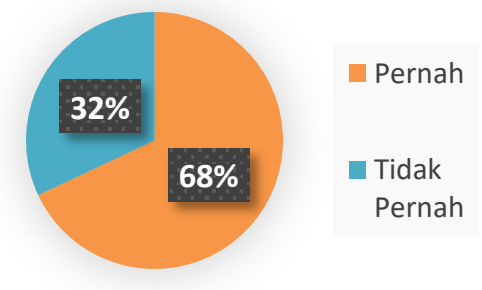

Sumber: Survey 2020

b. Apakah anda ingin menaiki kereta api ke kota Binjai?

- 52\% (13 orang) mengatakan ya.

- $28 \%$ (7 orang) mengatakan tidak.

- $20 \%$ (5 orang) mengatakan mungkin.

Diagram 2. Data Transportasi Kereta Api

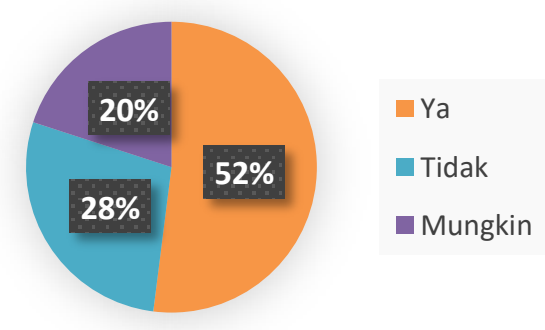

Sumber: survey 2020

c. Apa tujuan anda ke Binjai?

- 40\% (10 orang) mengatakan transit.

- 40\% (10 orang) mengatakan kuliner.
- 20\% (5 orang) mengatakan pariwisata.

Diagram 3. Data Tujuan ke Binjai

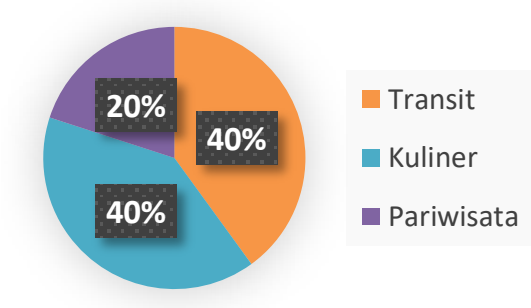

Sumber: Survey 2020

d. Apakah kota Binjai cocok menjadi kota transit?

- 48\% (12 orang) mengatakan ya.

- $24 \%$ (6 orang) mengatakan tidak.

- $28 \%$ (7 orang) mengatakan mungkin.

Diagram 4. Data Kota Transit

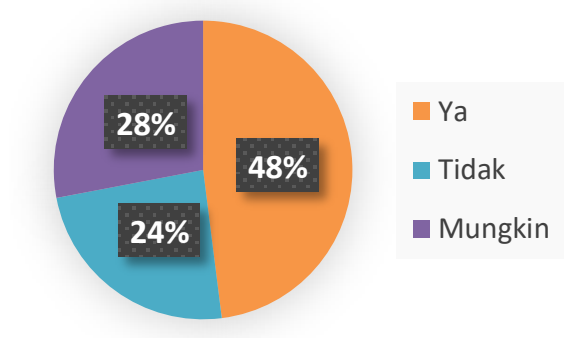

Sumber: survey 2020

e. Apakah masyarakat Binjai ramah tamah?

- 100\% (25 orang) mengatakan masyarakat Binjai ramah tamah.

Diagram 5. Data Ramah Tamah Masyarakat

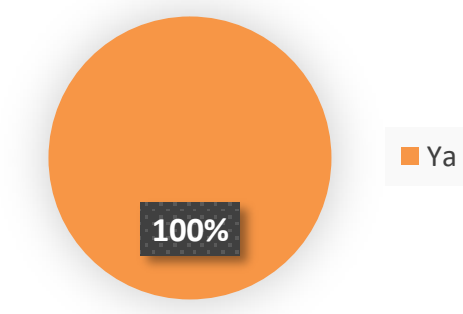

Sumber: survey 2020

2. Infrastruktur

a. Apakah kondisi jalan menuju Binjai bagus? 
- $64 \%$ (16 orang) mengatakan jalan menuju kota Binjai bagus.

- $36 \%$ (9 orang) mengatakan jalan menuju kota Binjai tidak bagus.

Diagram 6. Data Kondisi Jalan

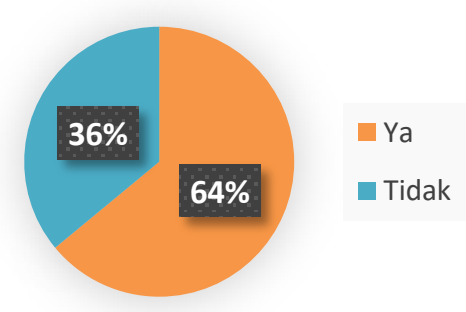

Sumber: survey 2020

b. Apakah fasilitas kereta api dari Medan menuju kota Binjai memadai?

- $72 \%$ (18 orang) mengatakan kereta api dari Medan menuju kota Binjai memadai.

- $28 \%$ (7 orang) mengatakan kereta api Medan menuju kota Binjai tidak memadai Diagram 7. Data Maintance Transportasi

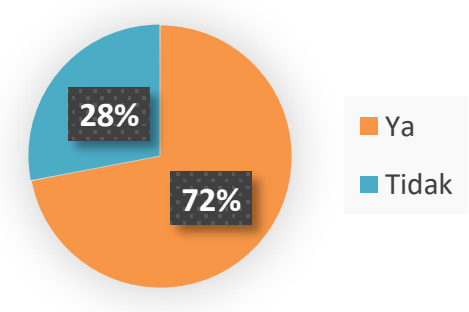

Sumber: survey $\mathbf{2 0 2 0}$

c. Apakah rambu-rambu jalan di daerah binjai sudah memadai?

- $65 \%$ (13 orang) mengatakan rambu-rambu jalan di daerah Binjai sudah memadai

-35\% (12 orang) mengatakan sebaliknya.

Diagram 8. Data Kondisi Rambu Lalu lintas

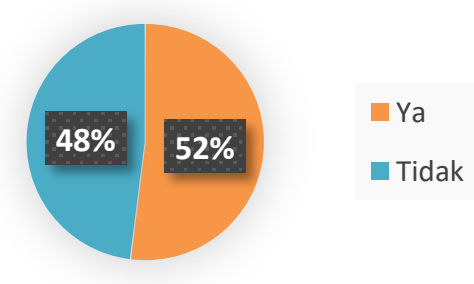

Sumber: survey 2020 d. Setujuhkah penambahan tujuan kereta api dari Binjai?

- 64\% (16 orang) mengatakan ya untuk penambahan kereta api dari Binjai.

- 36\% (9 orang) mengatakan tidak unutk penambahan kereta api dari Binjai.

Diagram 9. Data Penambah jalur kereta api

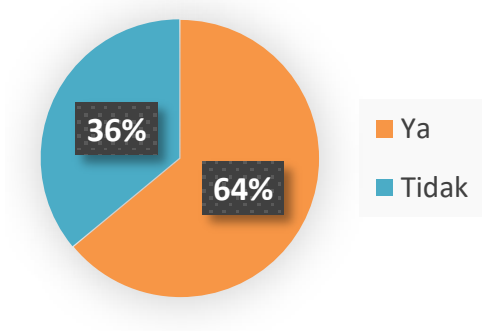

Sumber: survey 2020

\section{Harga}

a. Apakah harga tiket kereta api/bus sudah terjangkau?

- 64\% (16 orang) mengatakan harga tiket kereta api/bus standart.

- $4 \%$ (1 orang) mengatakan harga tiket kereta api/bus tidak terjangkau.

- $32 \%$ (8 orang) mengatakan tidak tahu.

Diagram 10. Data Harga tiket Kereta Api

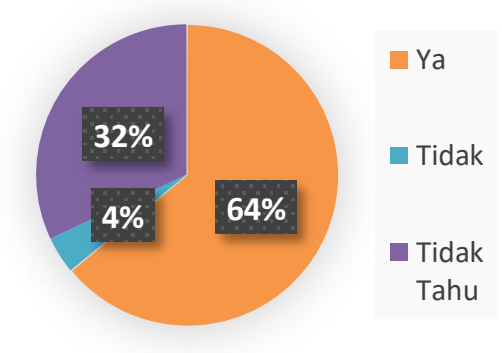

Sumber: survey 2020

b. Apakah harga tiket sesuai dengan fasilitas yang diberikan?

- 64\% (16 orang) mengatakan ya.

- $4 \%$ (1 orang) mengatakan tidak.

- $32 \%$ (8 orang) mengatakan tidak tahu. 
Diagram 11. Data Kesesuaian fasilitas dan harga tiket Kereta api

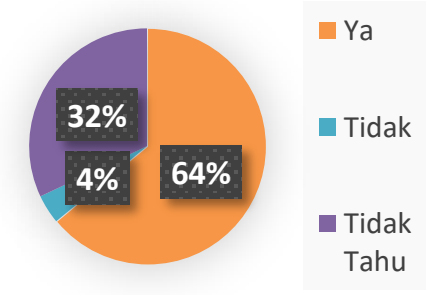

Sumber: survey 2020

\section{Kenyamanan}

a. Apakah anda setuju dengan adanya pedagang asongan di terminal?

- $64 \%$ (16 orang) mengatakan tidak setuju.

- 36\% (9 orang) mengatakan setuju.

Diagram 12. Data Keberadaan pedagang asongan di terminal

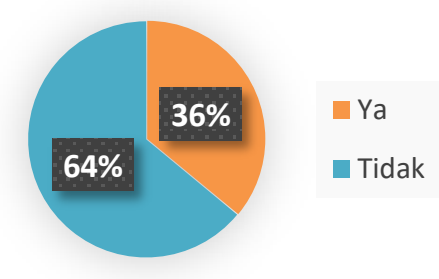

Sumber: survey 2020

b. Apakah anda tidak nyaman bila ada yang menawarkan jasa transportasi di stasiun kereta api?

- 20\% (5 orang) mengatakan merasa tidak nyaman dengan adanya penawaran jasa transportasi.

- $80 \%$ (20 orang) mengatakan merasa nyaman dengan adanya penawaran jasa transportasi.

Diagram 13. Data Kenyamanan penawaran jasa transportasi di stasiun kereta api.

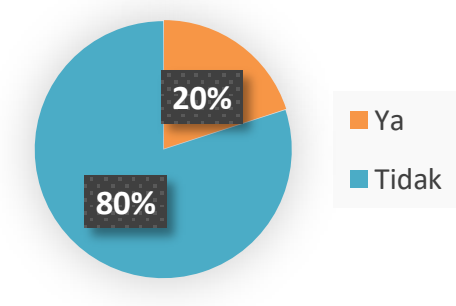

Sumber: survey 2020 c. Apakah anda merasa nyaman dengan transportasi yang sudah ada?

-72\% (18 orang) mengatakan merasa nyaman dengan transportasi yang sudah ada.

- $28 \%$ (7 orang) mengatakan tidak.

Diagram 14. Data Kenyamanan menggunakan jasa transporatasi

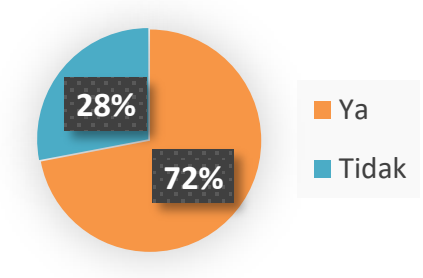

Sumber: survey 2020

II. Jumlah kuisioner (data teknis) yang disebarkan ke 25 responden mengenai Kota Binjai Sebagai Kota Transit antara lain umum, infrasturktur, harga, kenyamanan didapatkan data sebagai berikut:

\begin{tabular}{|l|c|c|c|c|c|c|c|}
\hline \multirow{2}{*}{ KECAMATAN } & \multicolumn{5}{|c|}{ PEKERJAAN } & \multirow{2}{*}{ TOTAL } \\
\cline { 2 - 7 } & D & M & K & P & PS & W & \\
\hline Binjai Kota & & & & & & & \\
\cline { 1 - 4 } Binjai Timur & 3 & 8 & 10 & 2 & 3 & 2 & 25 \\
\hline Binjai Selatan & & & & & & & \\
\hline
\end{tabular}

\begin{tabular}{|l|c|c|c|c|}
\hline \multirow{2}{*}{ KECAMATAN } & \multicolumn{3}{|c|}{ UMUR } & \multirow{2}{*}{ TOTAL } \\
\cline { 2 - 5 } & $\mathbf{1 1 - 2 0}$ & $\mathbf{2 1 - 3 0}$ & $\begin{array}{c}\mathbf{4 1}- \\
\mathbf{4 0}\end{array}$ \\
\hline Binjai Kota & \multirow{2}{*}{8} & 13 & 4 & 25 \\
\cline { 1 - 1 } Binjai Timur & & & & \\
\cline { 1 - 1 } Binjai Selatan & & & & \\
\hline
\end{tabular}

Sumber: Sumber Data, 2020

Keterangan:

- $\mathrm{D}=$ Designer

- $\mathrm{M} \quad=$ Mahasiswa/i

$\cdot \mathrm{K}=$ Karyawan

- $\mathrm{P} \quad=$ Pelajar

- PS = Pekerja Swasta

$\cdot \mathrm{W} \quad=$ Wirausaha 
Berdasarkan hasil pendataan kuisioner di atas maka didapatkan hasil berdasarkan 25 kuesioner diatas sebagai berikut:

a. Tahukah anda pengertian kota transit itu sebelumnya?

- $92 \%$ (23 orang) mengerti pengertian tentang kota transit.

- $8 \%$ (2 orang) tidak mengerti kota transit.

Diagram 15. Data Pengertian Kota Transit

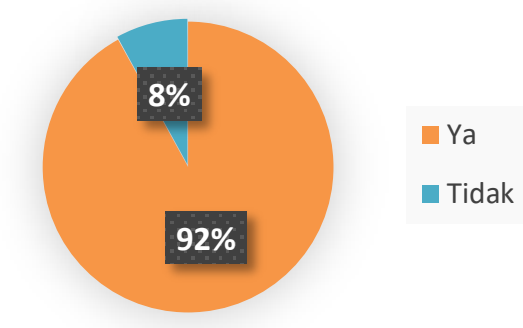

Sumber: survey 2020

b.Pernahkah sebelumnya anda menaiki transportasi yang ada di kota Binjai?

- 52\% (13 orang) pernah menaiki transportasi yang ada di kota Binjai.

- 48\% (12 orang) belum pernah menaiki transpotasi tersebut.

Diagram 16. Data Penggunaan transportasi di Kota Binjai

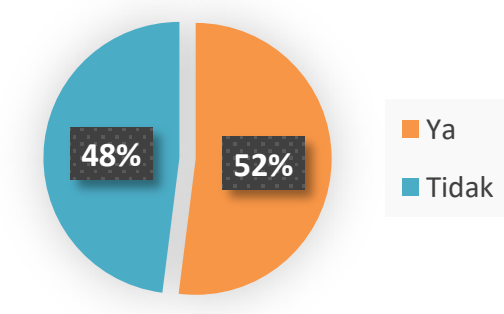

Sumber: survey 2020

c. Tujuan manakah yang akan anda lewati jika berpergian menggunakan transportasi di kota Binjai?

- 60\% (15 orang) kebanyakan berpergian menuju Medan.

- 20\% (5 orang) berpergian menuju Aceh.

- $20 \%$ (5 orang) berpergian sekitar Binjai.
Diagram 17. Data arah tujuan jika menggunakan transportasi dari Binjai

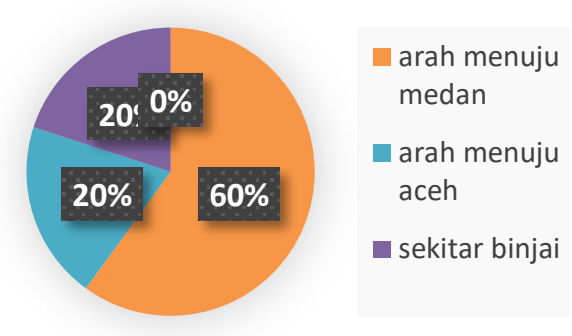

Sumber: survey 2020

d. Setujuhkah anda jika kota Binjai disebut dengan kota transit?

- 52\% (13 orang) mengatakan ya.

- 48\% (12 orang) mengatakan tidak.

Diagram18. Data Setuju Kota Binjai disebut

Kota Transit

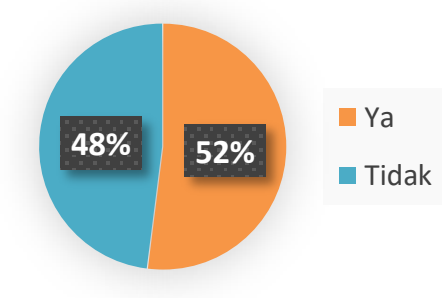

Sumber: survey 2020

1) Transportasi

a. Apakah anda setuju dengan penambahan jadwal keberangkatan bus/kereta api?

- 48\% (12 orang) mengatakan sangat setuju.

- $32 \%$ (8 orang) mengatakan setuju.

- 20\% (7 orang) mengatakan tidak setuju.

Diagram 19. Data Penambahan jadwal bus/kereta api

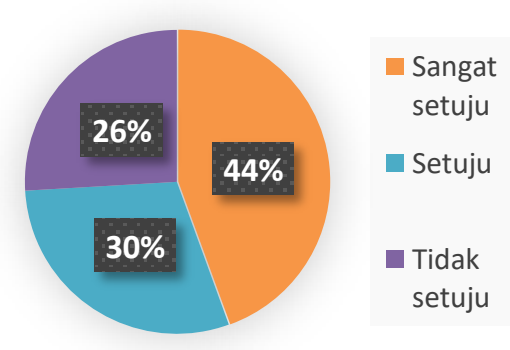

Sumber: survey 2020 
b. Apakah anda setuju dengan harga tiket di terminal bus?

- 92\% (23 0rang) mengatakan setuju dengan harga tiket terminal bus

- 8\% (2 orang) mengatakan tidak setuju.

Diagram 20. Data Kenyamanan harga tiket bus

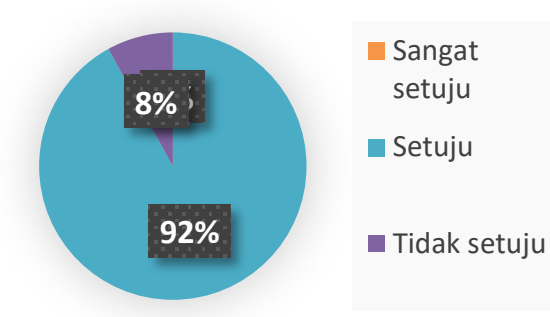

Sumber: survey 2020

c. Apakah anda setuju dengan rencana relokasi terminal bus?

- $100 \%$ (25 orang) tidak begi setuju tentang rencana relokasi terminal bus.

Diagram 21. Data Rencana Relokasi Terminal bus

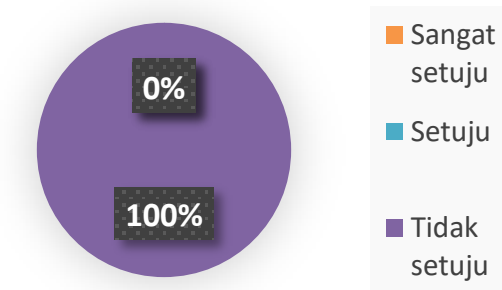

Sumber: survey 2020

d. Apakah anda setuju dengan rencana perluasaan/penambahan cabang terminal bus?

- $80 \%$ (20 orang) mengatakan sangat setuju

- $20 \%$ (5 orang) mengatakan tidak setuju
Diagram 22. Data Rencana perluasan cabang terminal bus

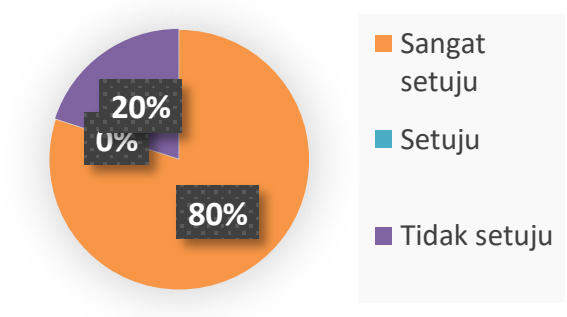

Sumber: survey 2020

\section{2) Fasilitas}

a. Apakah anda setuju dengan adanya selfservice di dalam kereta api?

- $60 \%$ (15 orang) mengatakan sangat setuju

- $20 \%$ (5 orang) mengatakan setuju.

- $20 \%$ (5 ornag) mengatakan tidak setuju

Diagram 23. Data Layak self service diterapkan di kereta api

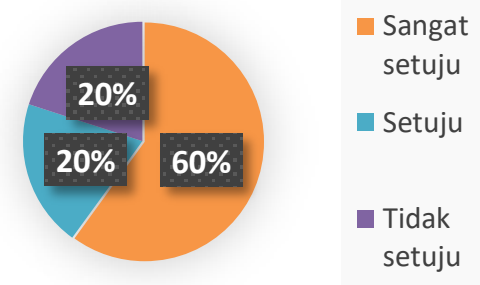

Sumber: survey 2020

b. Apakah anda setuju dengan adanya fasilitas penggunaan kartu sebagai pembayaran otomotis tanpa membeli tiket?

- 80\% (20 orang) mengatakan sangat setuju adanya fasilitas penggunaan kartu sebagai pembayaran otomatis.

- $20 \%$ (5 orang) mengatakan tidak setuju 
Diagram 24. Data Pembayaran penggunaan kartu pembayaran otomatis.

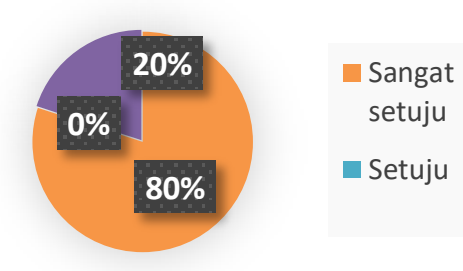

Sumber: survey 2020

c. Apakah anda setuju dengan adanya fasilitas retail untuk penjualan survenir, makanan, atau minuman?

- $80 \%$ (20 orang) mengatakan sangat setuju.

- $20 \%$ (5 orang) mengatakan tidak setuju.

Diagram 25. Data Fasilitas retail

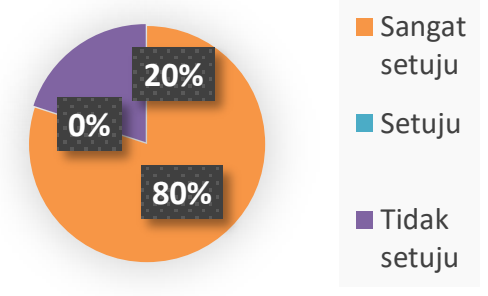

Sumber: survey 2020

d. Apakah anda setuju dengan adanya penambahan penerangan di sekitar terminal?

- $20 \%$ (5 orang) mengatakan sangat setuju.

- $80 \%$ (20 orang) mengatakan setuju.

Diagram 26. Data Penambahan Penerangan

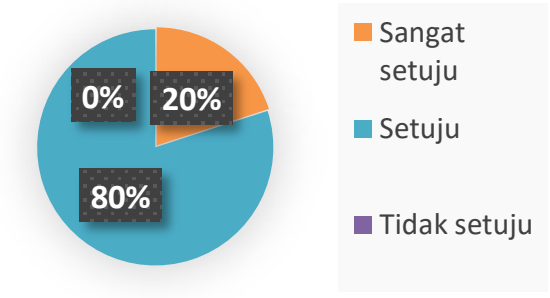

Sumber: survey 2020

\section{3) Warna}

a. Apakah anda setuju dengan design warna yang modern pada terminal bus?

- $20 \%$ (5 orang) mengatakan sangat setuju.

- $80 \%$ (20 orang) mengatakan setuju.
Diagram 27. Data Warna dan disain modern pada terminal bus.

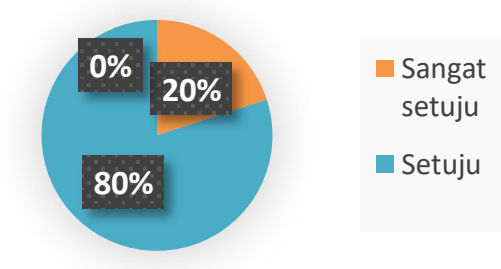

Sumber: survey 2020

b. Apakah anda setuju dengan design warna klasik pada stasiun kereta api?

- $60 \%$ (15 orang) mengatakan sangat setuju

- $20 \%$ (5 orang) mengatakan setuju.

- 20\% (5 ornag) mengatakan tidak setuju.

Diagram 28. Data Disain Warna Klasik

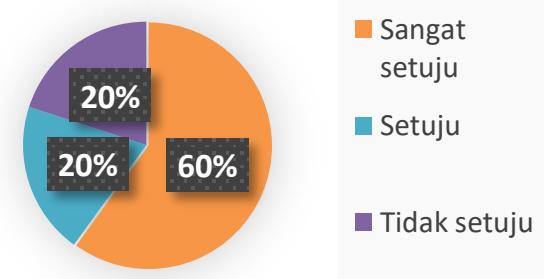

Sumber: survey 2020

c. Apakah anda setuju dengan adanya perubahan/penambahan warna untuk citra Kota Binjai?

- 48\% (12 orang) mengatakan sangat setuju.

- $32 \%$ (8 orang) mengatakan setuju.

- 20\% (7 orang) mengatakan tidak setuju.

Diagram 29. Data Perubahan warna ciri khas Binjai

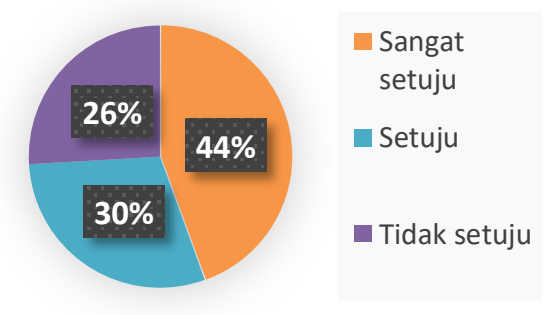

Sumber: survey 2020

d. Apakah anda setuju dengan sentuhan kreasi corak warna di dalam kereta api? 
- 48\% (12 orang) mengatakan sangat setuju.

- $32 \%$ (8 orang) mengatakan setuju.

- $20 \%$ (7 orang) mengatakan tidak setuju Diagram 30. Data Sentuhan Kreasi warna didalam kereta api

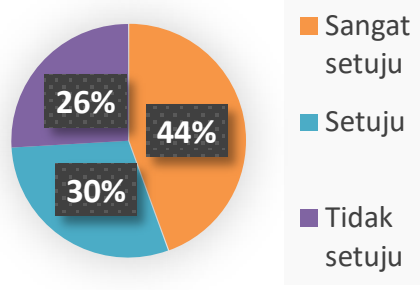

Sumber: survey 2020

\section{4) Rambu/signage}

a. Apakah anda setuju dengan adanya rambu aktifitas pada suatu kota dapat bekerja secara efektif?

- $80 \%$ (20 orang) mengatakan sangat setuju. - $20 \%$ (5 orang) mengatakan tidak setuju.

Diagram 31. Data Rambu aktifitas

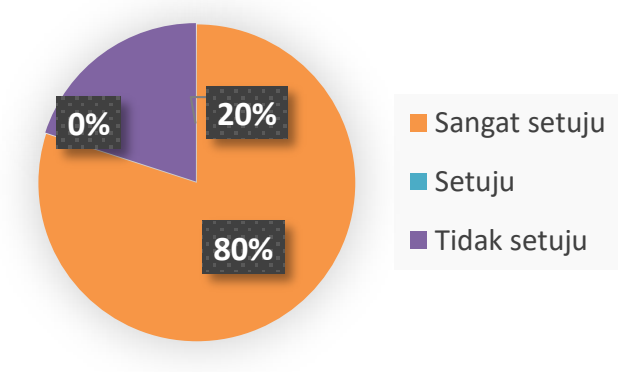

Sumber: survey 2020

b. Apakah anda setuju dengan penambahan rambu/signage pada terminal bus?

- $80 \%$ (20 orang) mengatakan sangat setuju.

- $20 \%$ (5 orang) mengatakan tidak setuju.
Diagram 32. Data Penambah rambu pada terminal

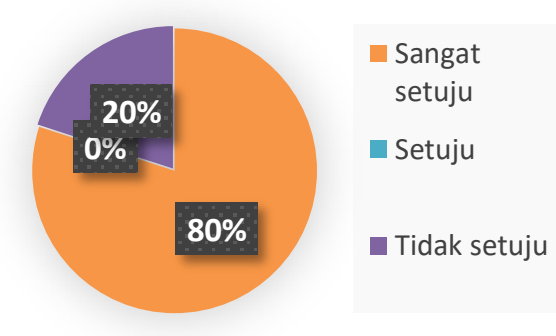

Sumber: survey 2020

c. Apakah anda setuju dengan adanya signage di dalam stasiun kereta api?

- $80 \%$ (20 orang) mengatakan sangat setuju.

- $20 \%$ (5 orang) mengatakan tidak setuju.

Diagram 33. Data Signage dalam kereta api

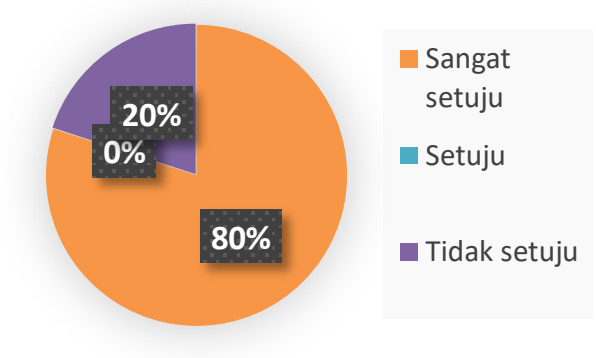

Sumber: survey 2020

d. Apakah anda setuju dengan adanya orang yang dapat membantu pengunjung terhadap rambu/signage seperti security, resepsionis? - $80 \%$ (20 orang) mengatakan sangat setuju. - 20\% (5 orang) mengatakan tidak setuju. Diagram 34 Data penambahan sosok dalam penunjuk signage

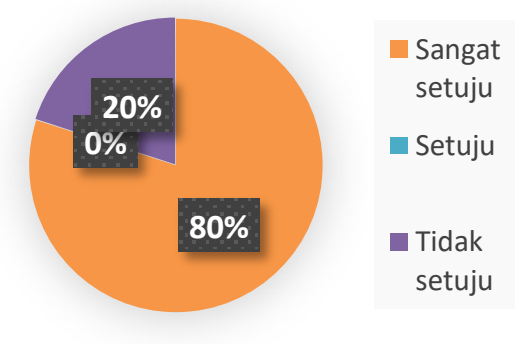

Sumber: survey 2020 


\section{KESIMPULAN}

Berdasarkan hasil penyebaran
kuisioner dan wawancara dengan masyarakat banyak hal yang antusias dalam pembenahan potensi wilayah perencanaan di Kota Binjai. Mengingat Kota Binjai merupakan salah satu daerah dalam proyek pembangunan MEBIDANGRO yang meliputi kawasan medan, binjai, deli sedang dan karo. Saat ini, Binjai dan Medan dihubungkan oleh jalan raya lintas sumatera yang menghubungkan antara Medan dan Banda Aceh. Oleh karena ini binjai terletak di daerah strategis di mana merupakan pintu gerbang Kota Medan ditinjau dari provinsi Aceh. Beberapa saran untuk menjadikan Kota Binjai menjadi kota transit memiliki fasilitas dan pembenahan dari aspek sosial dan teknisnya. Pembenahan dari segi transportasi baik kereta api dan bus. Pengembangan jalur transportasi dalam mengatasi efesiensi waktu tiba dan kepadatan penumpang. Potensi Pariwisata pun tak kalah harus diperhatikan sebagai magnet kegiatan masyarakat dalam meningkatkan perekonomian wilayah.

\section{DAFTAR ISI}

Darsono, Valentinus (1995), “Pengantar Ilmu Lingkungan.” Yogyakarta, Penerbitan Universitas Atma Jaya

Neri Ari Suma, S.STP., MH. (2019). Binjai Selatan Dalam Angka 2019. Edisi Pertama. Binjai : BPS Kota Binjai.

Sunanto, SE. (2019).Indikator Ketenagakerjaan Kota Binjai tahun 2019. Edisi Pertama. Binjai : BPS Kota Binjai.

Sunanto, SE. (2019).Statisktik Daerah Kecamatan Binjai Barat 2019. Edisi Pertama. Binjai : BPS Kota Binjai.
Sunanto, SE. (2019).Statisktik Daerah Kecamatan Binjai Kota 2019. Edisi Pertama. Binjai : BPS Kota Binjai.

Tjiptono, Fandy (2001), “Kualitas Jasa Pengukuran, Keterbatasan dan Implikasi Manajerial", Majalah Manajemen Usahawan Indonesia.

Sirojuzilam, 2011. "Regional Pembangunan, Perencanaan dan Ekonomi." USU press, Medan.

Suwantoro, 1997. "Prinsip Dasar Pembangunan Ekonomi Daerah." Makalah pada Seminar Pariwisata. Jakarta.

Sidabutar, Yuanita FD, Sirojuzilam,Suwardi Lubis dan Rujiman, 2018. "The Influence Of Building Quality, Environmental Conditions of Historical Building dan Community Participation to Cultural Tourism in Medan City." International Journal of Civil Engineering and Technology IJCIET), Volume 9, Issue 3, March 2018, pp. 259-270, article ID; IJCIET_09_03_028. IAEME Publication. Scopus Indexed. (http://www.iaeme.com/IJCIET/inde

x.asp, editor@iaeme.com

Sidabutar, Yuanita FD, 2007. "Pemanfaatan Keberadaan Bangunan Bersejarah Dalam Mendukung Aktifitas Pengembangan Wilayah Kota Medan," Jurnal Wahana Hijau, Medan. Vol. 3 Nomor 1, Agustus 2007. 